\title{
Kantiana w zasobie Archiwum Państwowego w Olsztynie - raport z badań
}

\section{Wprowadzenie}

Kluczowym celem podjętych badań jest wyselekcjonowanie, opracowanie, digitalizacja, a następnie udostępnienie w formie elektronicznej wraz z komentarzem wybranych dokumentów Uniwersytetu Albrechta w Królewcu, które związane są $\mathrm{z}$ działalnością fakultetu filozoficznego oraz $\mathrm{z}$ osobą samego Immanuela Kanta ${ }^{1}$. Akta uczelni królewieckiej, odnalezione w pierwszych latach powojennych $\mathrm{w}$ ramach prowadzonej akcji zabezpieczania dóbr kultury, przechowywane są obecnie w zasobie Archiwum Państwowego

\footnotetext{
${ }^{1}$ Zamysł digitalizacji i udostępnienia w formie elektronicznej kantianów z zasobu APO może być traktowany jako dopełnienie wcześniejszych inicjatyw upublicznienia pism Kanta, jak np. Korpora.org (http://www.korpora.org/Kant/), a w dalszej kolejności Project Gutenberg (http://www.gutenberg.org/), Zeno.org czy Archive.org, w których znalazły się jego teksty filozoficzne w wersji elektronicznej. Warto zaznaczyć, że zdigitalizowane i udostępniane na tych stronach materiały, w przypadku dokumentacji Albertyny czy podań Kanta mają nierzadko po kilka kopii, jednakże - jak pokazały badania porównawcze - nie zawsze ich treść jest identyczna, każdy zatem może być traktowany jako unikalny. Jest to jeden $\mathrm{z}$ argumentów uzasadniających pomysł selekcji, opracowania i publikacji materiałów z zasobu APO.
} 
w Olsztynie (dalej: APO) ${ }^{2}$. Na użytek publikacji wybrano kilka dokumentów, poddano je digitalizacji, opracowaniu i skomentowano. Artykuł dokumentuje przygotowania do szerszego projektu publikacji kantian z zasobu APO.

2. Ogólna charakterystyka zespołów archiwalnych: nr 1646

Uniwersytetu Albrechta w Królewcu i nr 1647

Kuratorium Uniwersytetu Albrechta w Królewcu

Mając na uwadze przeprowadzenie pełnej kwerendy i wyselekcjonowanie możliwie wszystkich materiałów dotyczących różnych aspektów życia i działalności zawodowej Immanuela Kanta, należy - prócz akt Uniwersytetu Albrechta w Królewcu - objąć poszukiwaniami również akta jego Kuratorium. Choć ewidencyjnie (ze względu na pochodzenie) materiały archiwalne stanowią dwa oddzielne zespoły, mają one jednak liczne powiązania. Wynikają m.in. z tego, że po likwidacji Etatsministerium z początkiem XIX wieku Kuratorium przejęło kuratelę nad działalnością uczelni. Uniwersytet w latach 1919 oraz 1921 przekazał w depozyt część swoich akt. Trafiły one do Państwowego Archiwum w Królewcu (Staatsarchiv Königsberg). W swojej registraturze pozostawiono dokumenty najstarsze, najcenniejsze oraz te, bez których codzienne zarządzanie uczelnią byłoby niemożliwe. W dwa lata później Kuratorium uczyniło to samo. Jego akta jako repozytura nr 99 zostały przyjęte do zasobu Państwowego Archiwum w Królewcu. Oba wspomniane zespoły wraz z innymi aktami po 1945 roku w wyniku ewakuacji Królewca trafiły do archiwum olsztyńskiego.

Porównując objętość zespołów akt przed wojną i po niej, można stwierdzić, że w obu przypadkach zostały znacznie uszczuplone. Pierwotnie zespół Uniwersytetu liczył 2750 jednostek akt (j.a.) z lat 1544-1935. Obecnie liczba zachowanych akt to 1892 j.a. $z$ lat 1554-1933. Nieco ponad 680 akt Kuratorium z lat 1577-1908 przechowywano w Królewcu, aktualnie w Olsztynie znajduje się zaledwie 369 z tych samych lat. Większość w zespole Uniwersytetu stanowią akta senatu oraz akta czterech wydziałów (teologicznego, medycznego, prawnego i filozoficznego) oraz akta sądowe. W obrębie akt senackich można wyodrębnić kilkanaście jednorodnych, dość licznych serii. Są to m.in.

${ }^{2}$ J. Judziński podaje Myślibórz jako powojenne miejsce odnalezienia akt Uniwersytetu. Por. J. Judziński, Archiwum Państwowe w Olsztynie 1945-1995, [w:] Pół wieku polskiej państwowej służby archiwalnej na ziemiach zachodnich i północnych, red. Kazimierz Kozłowski, Warszawa-Szczecin 1997, s. 119-140. 
protokoły rektora (1642-1752), protokoły senatu (1638-1904), rozporządzenia, statuty, przywileje, akta osobowe wykładowców, spisy studentów, spisy wykładów, stypendia, promocje oraz rachunki. Zróżnicowana jest liczba akt poszczególnych wydziałów. Czasem są one nieliczne (jedynie 8 j.a. fakultetu prawnego lat 1610-1873), w innym przypadku liczniejsze - 136 j.a. fakultetu medycznego $\mathrm{z}$ lat 1632-1911. Akta fakultetu filozoficznego w liczbie 60, $\mathrm{z}$ lat 1561-1917 obejmują: statut z 1561 roku, 3 księgi wydziału (z lat 1731-1772 i 1793-1845), akta dziekanów (z lat 1762-1763; 1815-1900), akta dotyczące kadry profesorskiej (z lat 1624-1868), rachunki (z lat 1719-1917) oraz akta merytoryczne. Nie wszystkie wspomniane archiwalia są przedmiotem badań. Główne kryteria selekcji stanowi chronologia oraz materia akt.

\section{Historia dotychczasowych badań nad archiwaliami z Królewca (projekt Kants Amtstätigkeit)}

Akta uniwersytetu królewieckiego, przechowywane w zasobie APO, zostały zinwentaryzowane w latach sześćdziesiątych przez Tadeusza Grygiera i ponownie zewidencjonowane w latach 1990-1993². Niejednokrotnie były przedmiotem wycinkowych (fragmentarycznych) kwerend naukowych, jednak najobszerniejszą w pierwszej połowie latach dziewięćdziesiątych przeprowadzili niemieccy historycy filozofii. Ówczesne badania były częścią dwuletniego projektu zatytułowanego „Działalność urzędowa Kanta” (Kants Amtstätigkeit), którym kierował Reinhardt Brandt z Instytutu Filozofii Philipps-Universität w Marburgu. Uczestniczyli w nim również Werner Euler i Werner Stark z Marburga oraz Steffen Dietzsch (wówczas z Humboldt-Universität w Berlinie). Badania zmierzały głównie do zdokumentowania oraz historycznej rekonstrukcji działalności zawodowej Kanta jako profesora, senatora, dziekana oraz rektora królewieckiego uniwersytetu ${ }^{4}$. Kwerendę pro-

\footnotetext{
${ }^{3}$ B. Wacławik, Archiwalia do dziejów Uniwersytetu Królewieckiego przechowywane w Archiwum Państwowym w Olsztynie, „Archeion” 1995, t. XCV, s. 58-65. Sposób uporządkowania akt fakultetu filozoficznego w zasobie APO w ujęciu historycznym i rzeczowym prezentuje artykuł B. Wacławik, Akta Wydziału Filozoficznego Uniwersytetu w Królewcu przechowywane w Archiwum Państwowym w Olsztynie, [w:] Historia Archiwistyka Informacja Naukowa, red. Marzena Świgoń, Wyd. UWM w Olsztynie, Olsztyn 2009, s. 229-231.

${ }^{4}$ W. Euler, Kants Amtstätigkeit - ein neues Projekt der Kantforschung, „Information Philosophie" 1992, H. 5, s. 76.
} 
wadzono pod egidą Deutche Forchungsgemeischaft ${ }^{5}$. Jednym z ważniejszych wyników przeprowadzonych badań było m.in. odkrycie blisko stu nowych dokumentów ${ }^{6}$. Ostatecznym celem badań miało być stworzenie bazy danych, obejmującej sfilmowane, odczytane i skomentowane akta dotyczące Kanta w postaci obszernej publikacji. W ramach jednego, zakrojonego na dużą skalę projektu wraz z zasobem APO poddano badaniom dokumenty znajdujące się w berlińskim Tajnym Archiwum Państwowym (Geheimes Staatsarchiv Preussischer Kulturbesitz Berlin, GStA), ze szczególnym uwzględnieniem akt wschodniopruskiego Etatsministerium z byłego Archiwum Państwowego w Królewcu (Staatsarchiv Königsberg, StA) ${ }^{7}$.

${ }^{5}$ Efektem przeprowadzonych badań były liczne publikacje, m.in. S. Dietzsch, Immanuel Kant. Eine Biographie, Leipzig 2003 (polski przekł. K. Krzemieniowa, Warszawa 2005); W. Euler, Kantiana in Olsztyn, „Information Philosophie” 1993, H. 4, s. 78; W. Euler, S. Dietzsch, Der Dekan Immanuel Kant, „Universitas. Zeitschrift für interdisziplinäre Wissenschaft” 1994, Nr. 571, s. 97 i n.; W. Euler, S. Dietzsch, Prüfungspraxis und Universitätsreform in Königsberg. Ein neu aufgefundener Prüfungsbericht Kants aus dem Jahre 1779, [w:] Kant-Forschungen V, Hamburg 1994, s. 91-108; W. Stark, Kants Amtstätigkeit. Ein Kurzbericht zu einem Vorhaben der Deutschen Forschungsgemeinschaft, „Kant-Studien” 1994, Nr 85, s. 470-472; W. Stark, Kant als akademischer Lehrer, [w]: Wolfenbütteler Studien zur Aufklärung, Bd. 16, Hrsg. H. Ischreyt, Max Niemeyer Verlag, Tübingen 1995, s. 51-68; W. Euler, G. Stiening, ‘... und nie der Pluralität widersprach'? Zur Bedeutung von Immanuel Kants Amtsgeschäften, „Kant-Studien” 1995, Nr 86, s. 54-69; G. Stiening, Immanuel Kant i historia Fakultetu Medycyny w Królewcu, „Komunikaty Mazursko-Warmińskie" 1995, nr 1, s. 53-64; W. Euler, Kant $w$ Senacie akademickim $w$ latach 1780-1801, „Komunikaty Mazursko-Warmińskie” 1995, nr 2, s. 131-142; W. Euler, Kants Beitrag zur Schul- und Universitätsreform im ausgehenden 18. Jahrhundert, [w:] Studien zur Entwicklung preußischer Universitäten, Hrsg. R. Brandt, W. Euler, W. Stark, Wiesbaden 1999; G. Stiening, Der 'Strich des Zensors' und die 'Freiheit der gelehrten Feder'. Immanuel Kant und die Universitätszensur, [w:] Studien zur Entwicklung preußischer Universitäten..., s. 163-201. Zob. także H. Marti, Die Quellenbestände zur frühneuzeitlichen Königsberger Universitätsgeschichte im polnischen Olsztyn (Allenstein) - Ein erster fragmentarischer Überblick, [w:] Königsberger Buch- und Bibliotheksgeschichte, Hrsg. A. E. Walter, Böhlau Verlag, Köln-Weimar-Wien 2004, s. 571-582.

${ }^{6}$ Por. W. Euler, S. Dietzsch, Der Dekan Immanuel Kant..., s. 98. W notce informacyjnej, opublikowanej w 1993 roku, Euler zwracał uwagę na pokaźną ilość dokumentów będących oryginalnymi pismami Kanta (listy, własne komentarze, różnego rodzaju sprawozdania, relacje, protokoły, zaświadczenia), które znajdują się w Olsztynie i w znacznej części nigdy wcześniej nie były publikowane. Podczas kwerendy okazało się jednak, że zasoby są niekompletne i wymagały ponownego uporządkowania pod kątem celów zaplanowanych badań. Zob. W. Euler, Kantiana in Olsztyn..., s. 78.

${ }^{7}$ W. Euler, Kants Amtstätigkeit - ein neues Projekt der Kantforschung...., s. 76. 
Wysiłki badawcze zmierzały nie tylko do rekonstrukcji i udostępnienia materiałów, lecz przede wszystkim w części związanej z samym Kantem miały służyć wyjaśnieniu relacji między jego działalnością jako badacza, filozofa i autora oryginalnych publikacji oraz jako nauczyciela akademickiego oraz urzędnika uniwersytetu. Jak zauważa W. Euler, wielość pełnionych funkcji szła w parze z przekonaniem Kanta o ich wzajemnych zależnościach. Kant uważał się zatem i za lojalnego poddanego państwa pruskiego, i za świadomego indywidualnej odpowiedzialności obywatela oraz członka społeczności akademickiej ${ }^{8}$.

Innym, w pewnym sensie pobocznym (choć nie marginalnym), zadaniem badań z początku lat dziewięćdziesiątych była weryfikacja oraz uzupełnienie i poszerzenie prac, jakie nad dorobkiem Kanta prowadzono na przełomie XIX i XX wieku. Chodziło tu o badania E. Arnoldta z lat 1881-1904, E. Fromma (1894), A. Wardy z lat 1899-1919 oraz O. Schöndörffera $z$ lat 1904-1919. Ich rezultaty - jak pisał Euler - nie były wolne od pewnej przypadkowości, jak i niekompletności. Dodatkowo nie opierały się one na pełnej dokumentacji, gdyż nie była ona wówczas dostępna badaczom. Świadomość tego rodzaju ograniczeń i wartości osiągniętych wyników skłaniała do ponownego, gruntownego i systematycznego zajęcia się zagadnieniem działalności urzędowej Kanta, której rekonstrukcja powinna była się łączyć z konfrontacją materiałów archiwalnych, znajdujących się w różnych archiwach ${ }^{9}$. Podsumowując, trzeba podkreślić, że założony cel niemieccy badacze osiągnęli.

\section{Immanuel Kant w świetle materiału archiwalnego}

Dokumenty uniwersyteckie znajdujące się w zasobie APO pozwalają przede wszystkim na rekonstrukcję działalności akademickiej Kanta jako profesora zwyczajnego fakultetu filozoficznego, jakim był on od 1770 roku, oraz w okresie pełnienia różnych funkcji administracyjnych: jako członka senatu uczelni (od 1780 roku), jako dziekana fakultetu filozoficznego (sześciokrotnie) oraz jako rektora uniwersytetu (dwukrotnie, w latach 1786 i 1788). W całokształcie działalności profesorskiej, szczególnie w konfrontacji z badaniami i dociekaniami skoncentrowanymi na filozofii, zajęcia administracyjne w senacie oraz związane $\mathrm{z}$ obowiązkami dziekańskimi i rektorskimi jak może się wydawać - miały drugorzędne znaczenie. Pozwalają jednak - na

\footnotetext{
${ }^{8}$ Por. W. Euler, Kantiana in Olsztyn..., s. 78.

${ }^{9}$ Zob. W. Euler, Kants Amtstätigkeit - ein neues Projekt der Kantforschung..., s. 77.
} 
co wielokrotnie zwracali uwagę Euler oraz Dietzsch - poznać praktyczną stronę działalności zawodowej, charakterystyczne dla niej wieloletnie zaangażowanie w codzienne funkcjonowanie uniwersytetu, jego uwarunkowania i specyfikę. Dokumenty są w takich przypadkach źródłowym materiałem pozwalającym śledzić wiele spraw i procesów, zarówno o znaczeniu lokalnym, związanym bezpośrednio z Albertyną i Królewcem (m.in. cotygodniowe obrady senatu uczelni, sprawy bieżące, podejmowane w nich decyzje), jak również o znaczeniu uniwersalnym (wydarzenia polityczne, państwowe, planowane i prowadzone reform systemu oświaty itp.).

O potrzebie i wartości badań nad tą częścią działalności uniwersyteckiej Kanta przekonany był m.in. S. Dietzsch. We wstępie do polskiego wydania swojej monografii podkreślał istotną rolę zarówno zasobów, jak i samego APO we współczesnych badaniach nad spuścizną kantowską. Olsztyńska instytucja dzięki posiadanym zespołom archiwalnym, obok uznanych niemieckich ośrodków, takich jak archiwum Kanta przy uniwersytecie w Marburgu (Marburger Archiv) ${ }^{10}$ oraz Ośrodek Badań Kantowskich w Moguncji (Kant Forschungsstelle der Johannes Guttenberg-Universität Mainz) ${ }^{11}$, stanowi „trzecie - jak pisał - wielkie centrum przyszłych badań źródłowych nad życiem i dziełem tego filozofa oraz jego wschodniopruskim otoczeniem"12. Szczególnie ważna wydaje się ostatnia część uwagi Dietzscha. Olsztyńskie zbiory okazały się przydatne do badań historycznych, społecznych, kulturowych oraz politycznych nad uwarunkowaniami rozwoju Albertyny, w tym fakultetu filozoficznego oraz nad działalnością urzędową samego Kanta. Protokoły, rejestry, inne pisma urzędowe pozwalają odtworzyć nie tylko merytoryczną treść spraw, z którymi były związane, ale również rzucają światło na poglądy, stanowiska, toczone dyskusje i spory wokół bieżących problemów Albertyny.

Rozstrzygnięcia wymaga kluczowe pytanie o wartość materiałów znajdujących się w APO i ich przydatność do badań na dorobkiem I. Kanta. Wyniki dotychczasowych badań niemieckich historyków filozofii (m.in. Eulera, Starka, Dietzscha, Stieninga), a także polskich historyków i archiwistów

\footnotetext{
${ }^{10}$ Zob. Marburger Archiv - Kant und die Aufklärung,

http://www.uni-marburg.de/fb03/philosophie/mr_archiv (data dostępu 7.04.2014).

11 Zob. Kant Forschungsstelle der Johannes Guttenberg-Universität Mainz, http://www.kant.uni-mainz.de/ (data dostępu 7.04.2014).

12 Przedmowa do polskiego wydania, w: S. Dietzsch, Immanuel Kant. Biografia, przeł. K. Krzemieniowa, Warszawa 2005, s. 11. Warto je uzupełnić przynajmniej o Kant Forschungsstelle Uniwersytetu w Trier oraz o ośrodek, jakim jest Uniwersytet w Siegen.
} 
(m.in. D. Bogdan i B. Wacławik) nad dokumentacją Albertyny ${ }^{13}$ pokazują, że istnieje przynajmniej kilka ścieżek analiz i ocen. Wśród ważniejszych warto wymienić analizy historyczno-rekonstrukcyjne, które odnoszą się do działalności uniwersytetu w Królewcu, jego politycznego, społecznego i kulturowego otoczenia, reform systemowych itp. Innym tropem badawczym jest działalność samego Immanuela Kanta jako dziekana i rektora Albertyny. $\mathrm{W}$ tym wymiarze można próbować oceniać jego bezpośrednie zaangażowanie w rozwój uniwersytetu (np. unowocześnienie fakultetu medycznego) oraz pośrednie zaangażowanie $w$ reformy ówczesnego systemu edukacji na poziomie szkół i uniwersytetów państwa pruskiego ${ }^{14}$. Inną kwestią jest ranga fakultetu filozoficznego w funkcjonowaniu uniwersytetu. Jak wiadomo, w strukturze ówczesnych niemieckich uczelni spełniał on głównie funkcję pomocniczą i propedeutyczną w całokształcie działalności dydaktycznej, przygotowując studentów do dalszej nauki na jednym z wyższych fakultetów (medycznym, prawnym lub teologicznym). To szczególne usytuowanie uprawniało jego przedstawicieli do formułowania krytycznych uwag na temat funkcjonowania uczelni, ocen obowiązującego oraz wskazywania pożądanego modelu kształcenia. Światło na tę ostatnią sprawę rzucają m.in. rozważania samego Kanta, zawarte w Sporze fakultetów ${ }^{15}$. Wyrażone tam poglądy poddają się wówczas nie tylko egzegezie czy analizie, ale również konfrontacji z bogatą działalnością administracyjną i powiązaną z nią dokumentacją bieżących działań jako profesora, senatora, a z czasem jako dziekana i rektora ${ }^{16}$.

Z powodu tematycznej różnorodności dokumentów Albertyny w APO konieczne jest przyjęcie przynajmniej dwóch kryteriów selekcji dokumentów

13 Por. B. Wacławik, Akta Wydziału Filozoficznego Uniwersytetu w Królewcu..., s. 227-232; B. Wacławik, Die Tätigkeit des Senats der Königsberger Universität im Spiegel von Protokolen der Jahre 1725-1795, [w:] Studien zur Entwicklung preußischer Universitäten, Hrsg. R. Brandt, W. Euler, Harrassowitz Verlag, Wiesbaden 1999, s. 81-94; D. Bogdan, Besuch der Vorlesungen durch Studenten der Theologischen Fakultät der Königsberger Universität in den 70er und 80er Jahren des 18. Jahrhunderts, [w:] Studien zur Entwicklung preußischer Universitäten..., s. $95-112$.

${ }^{14}$ Por. także W. Euler, Kants Beitrag zur Schul- und Univerisitätsreform im ausgehenden 18. Jahrhundert, [w:] Studien zur Entwicklung preußischer Universitäten..., s. 203-272.

${ }^{15}$ I. Kant, Spór fakultetów, [w:] idem, Dzieła zebrane, t. 5, red. W. Włoch, przeł. M. Żelazny, Wydawnictwo Naukowe UMK, Toruń 2011, s. 194-285.

${ }_{16}$ Wszechstronnie ukazał to m.in. G. Stiening. Interesującą rekonstrukcję postępowego i przychylnego stanowiska Kanta wobec fakultetu medycznego przedstawił w artykule Immanuel Kant i historia Fakultetu Medycyny w Królewcu, „Komunikaty Mazursko-Warmińskie” 1995, nr 1, s. 53-64. 
i ich późniejszej interpretacji. W obu przypadkach wiążą się one z Kantem. Raz występuje on jako ich autor, jako strona w sprawie, innym zaś razem dokumenty i sprawy odnoszą się do niego ${ }^{17}$. Są to zaświadczenia, zaprotokołowane wypowiedzi, decyzje, wpisy (niekiedy także własnoręczne) do semestralnych i rocznych wykazów prowadzonych wykładów, a także różnego rodzaju dokumenty finansowe.

\section{Między urzędem a ideami, wartościami i duchem epoki}

Generalne nastawienia Kanta zarówno do wartości własnej filozofii, głoszonych poglądów, jak również do pozanaukowej sfery jego pracy (podejmowanych z urzędu decyzji i zewnętrznej sytuacji, wyznaczającej możliwości jego działania) wymaga tego, by oceniać dokumenty uniwersyteckie w szerszej perspektywie, aniżeli wynikałoby to tylko z przedmiotu spraw, jakich bezpośrednio dotyczą. Przekonanie o wartości badań nad działalnością administracyjną Kanta jest następstwem uznania, że filozofia praktyczna i pozostałe głoszone poglądy mogą stanowić tło i swoisty komentarz do podejmowanych decyzji i działań jako profesora, członka senatu, dziekana czy rektora. Przy takim założeniu Kant przedstawia się jako zwolennik stanowiska, które uzasadnia potrzebę istnienia odrębnego i autonomicznego fakultetu filozoficznego, a jego rolę sprowadza do fundamentalnego i powszechnego prawa oceny (osądzania) wszelkich decyzji, odnoszących się „do interesów nauki” $\mathrm{w}$ imię racji oraz prawdy ${ }^{18}$. Warto podkreślić, że istotne argumenty Kanta na rzecz uznania szczególnej roli fakultetu filozoficznego w strukturze i funkcjonowaniu uniwersytetu jako wspólnoty uczonych wynikają nie $\mathrm{z}$ doraźnych i praktycznych względów, a z czysto apriorycznych racji. Te zaś pozwalają zbudować zrozumiałą hierarchię w strukturze instytucji, analogicznie jak w przypadku porządku i hierarchii celów rządzenia. O owej hierarchiczności Kant pisał następująco: „najpierw wieczne dobro każdego, potem dobro obywatelskie każdego jako członka społeczeństwa, w końcu fizyczne dobro (długie życie i zdrowie)"19. Wynikająca z tej hierarchii potrzeb i celów racjo-

17 Przykładem drugiego rodzaju dokumentów były np. zapisy w rejestrach finansowych, dokumentujące dokonanie wpłaty $\mathrm{z}$ tytułu promocji magisterskiej w 1755 roku po złożeniu 13 maja tego roku wymaganych examen rigorosum. APO, 1646/ s. 298.

18 I. Kant, Spór fakultetów..., s. 203-204.

${ }^{19}$ Tamże, s. 204. Komentarzem do tych uwag może być spostrzeżenie Kant o roli i sytuacji filozofii. Myśliciel dostrzegał w niej pewną niespójność, z jednej bowiem strony (z racji erudycji) jest nauką ścisłą, czyli fizyką, z drugiej natomiast jest ona środkiem i narzędziem mądrości. 
nalna hierarchia wyższych fakultetów jest łatwa do określenia i uzasadnienia. Zgodnie z nią, pierwsze miejsce zajmuje fakultet teologiczny, następne prawny, a kolejne medyczny:

Lekarz jest dla nas najważniejszym człowiekiem na mocy instynktu naturalnego, gdyż przedłuża on nam życie, później następuje prawnik, który obiecuje chronić to, co do nas przypadkiem należy i tylko w ostateczności (niemal dopiero w chwili śmierci), choć chodzi o wieczne zbawienie, zwracamy się do duchownego, albowiem nawet osoba duchowna jakby nie zachwalała życia wiecznego, z powodu, że nie postrzega jego realności, życzy nam gorąco, byśmy przy pomocy lekarza wciąż jeszcze przez jakiś czas pozostali na ziemskim padole ${ }^{20}$.

Warto tu przypomnieć, że wewnętrzna organizacja fakultetu filozoficznego ukształtowała się wcześniej niż trzech pozostałych. Podstawową strukturę uregulowały statuty „Facultatis artium” z lat 1546 i 1554 i ich późniejsze zmiany. W skład fakultetu filozoficznego wchodziło osiem ordynariatów: języka hebrajskiego, języka greckiego, logiki z matematyką, fizyki praktycznej (od 1619 roku), fizyki (w pierwszej połowie XVII wieku przez blisko dwadzieścia lat była ona związana w wydziałem medycyny), poezji, retoryki i historii (połączonych w 1701 roku) ${ }^{21}$. Niejako wbrew swej nazwie fakultet filozoficzny organizował kształcenie w zakresie przedmiotów stanowiących encyklopedię i organon późniejszych studiów na jednym z trzech pozostałych fakultetów. Z tego względu, jak wskazuje Dietzsch, specyfiką pracy dydaktycznej była mnogość dziedzin, z jakich profesura fakultetu prowadziła zajęcia ze studentami, np. Kant poza wykładami z metafizyki nauczał logiki, geografii, trygonometrii czy nauk o człowieku ${ }^{22}$. Doskonałą ilustracją dydaktycznego zaangażowania profesorów fakultetu filozoficznego są semestralne spisy wykładów, znajdujące się w zasobie APO. Podział kompetencyjny obowiązujący w Albertynie sprawiał, że profesorowie fakultetu filozoficznego mogli wymiennie prowadzić wszystkie przedmioty z wyjątkiem tych, które należały do trzech pozostałych fakultetów. Z czasem, w XIX wieku, wraz

Wynika z tego, że bycie uczonym w tej dziedzinie zasadniczo różni się od czystego filozofowania, czyli bycia filozofem (Reflexionen zur Logik, podaję za: S. Dietzsch, Immanuel Kant. Biografia..., s. 182).

${ }^{20}$ Tamże, s. 205.

21 Por. S. Dietzsch, Fakultet Filozoficzny Uniwersytetu w Królewcu w latach 1744-1844, „Komunikaty Mazursko-Warmińskie" 1995, nr 1, s. 46.

${ }^{22}$ Zob. tamże. 
z dokonującym się postępem poznawczym i specjalizacją poszczególnych dyscyplin nauki ta wymienność ról i dyscyplin zanikła, profesjonalizując filozofię jako naukę akademicką. Swoistością fakultetu filozoficznego był brak hierarchizacji poszczególnych dziedzin wiedzy i równocześnie praw do ich wykładania. Jak współcześnie, także wówczas toczyły się dyskusje na temat roli kształcenia propedeutycznego (w tym przedmiotów filozoficznych sensu stricto) dla studiów i samych studentów. Wśród nich nierzadkie były sceptyczne sądy i postawy wobec wiedzy ogólnej.

Struktura organizacyjna Albertyny znajdowała odzwierciedlenie w składzie osobowym i sposobie działania senatu uczelni. Zasiadali w nim czterej najstarsi profesorowie fakultetu filozoficznego, obok nich zaś dwuosobowe reprezentacje pozostałych fakultetów. Praktyka rotacyjnego wyboru rektora uczelni przez senat powodowała, że przedstawiciel filozofów mógł nim zostać raz na osiem lat, a pozostałych fakultetów - raz na cztery lata ${ }^{23}$.

Dydaktyczna i organizacyjna rola fakultetu filozoficznego polegała nie tylko na kształceniu podstawowym i przygotowawczym do dalszych studiów, ale także obejmowała prowadzenie rekrutacji i egzaminów immatrykulacyjnych. Te ostatnie znajdowały się w kompetencjach dziekana fakultetu. Odpowiadał on również za organizację i prowadzenie egzaminów magisterskich przed kolegium fakultetu. Warto także wspomnieć, że szczególnym przywilejem Albertyny, wynikającym z prawa nadanego przez króla Zygmunta, było przyznawanie polskiego szlachectwa wypromowanym osobom ${ }^{24}$.

\section{Wybrane akta jako świadectwa działalności administracyjnej Kanta}

Kant $\mathrm{w}$ okresie prywatnej docentury trzykrotnie bezskutecznie ubiegał się o przyjęcie na etat profesora fakultetu filozoficznego. Potwierdzeniem tych starań było m.in. pismo, które wystosował do senatu uczelni 11 grudnia 1758 roku, a więc już dzień po śmierci Johanna Davida Kypkego, wykładowcy filozofii i teologii ${ }^{25}$. Dwa dni później napisał również pismo do cesarzowej

${ }^{23}$ Por. S. Dietzsch, Fakultet Filozoficzny Uniwersytetu w Królewcu w latach 1744-1844..., s. 47.

${ }^{24} \mathrm{~W}$ nawiązaniu do pracy L. von Baczko wspomina o tym S. Dietzsch (tamże, s. 48).

${ }^{25}$ S. Dietsch błędnie podaje, że Kypke zmarł 12 grudnia 1758 roku, co pozostawałoby w sprzeczności z datą i treścią pisma Kanta. Por. S. Dietzsch, Immanuel Kant..., s. 81. Por. np. The Dictionary of Eighteenth Century German Philosophers, 3 vols., Manfred Kühn and Heiner Klemme (ed.), Continuum, London/New York 2010), fragment poświęcony J. D. Kypkemu:

http://www.manchester.edu/kant/bio/FullBio/KypkeJD.html (data dostępu: 24.04.2014) http://www.manchester.edu/kant/bio/biokon.htm\#KypkeJD (data dostępu: 24.04.2014) 
Elżbiety z prośbą o powierzenie mu wolnego etatu ${ }^{26}$. Próby okazały się jednak bezskuteczne. Stanowisko profesorskie otrzymał Friedrich Johann Buck. Kolejną próbę Kant podjął po śmierci Johanna Georga Bocka, który zmarł 7 lipca 1762 roku. Sprawa ciągnęła się ponad dwa lata i także zakończyła się niepowodzeniem. To ostatecznie skłoniło Kanta do szukania poparcia u króla i do złożenia wniosku o zatrudnienie w uczelni na etacie młodszego bibliotekarza.

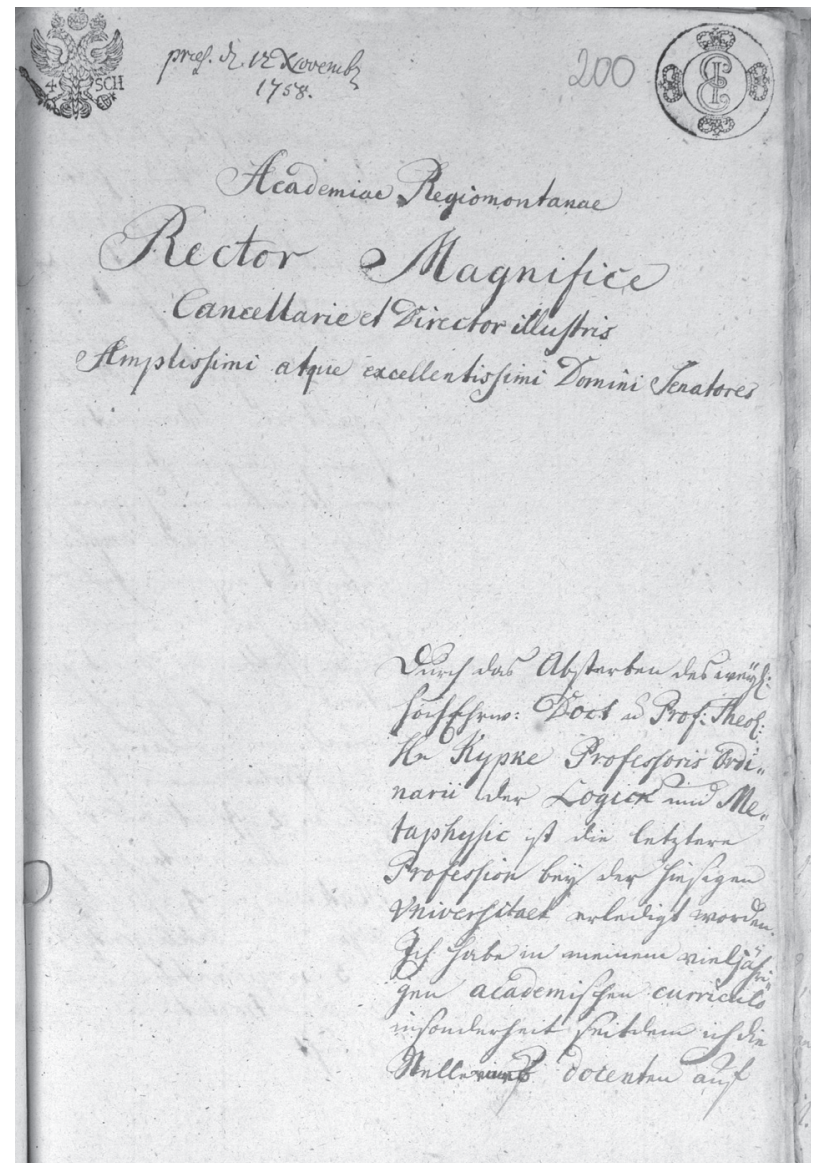

${ }^{26}$ S. Dietzsch, Immanuel Kant..., s. 81. 


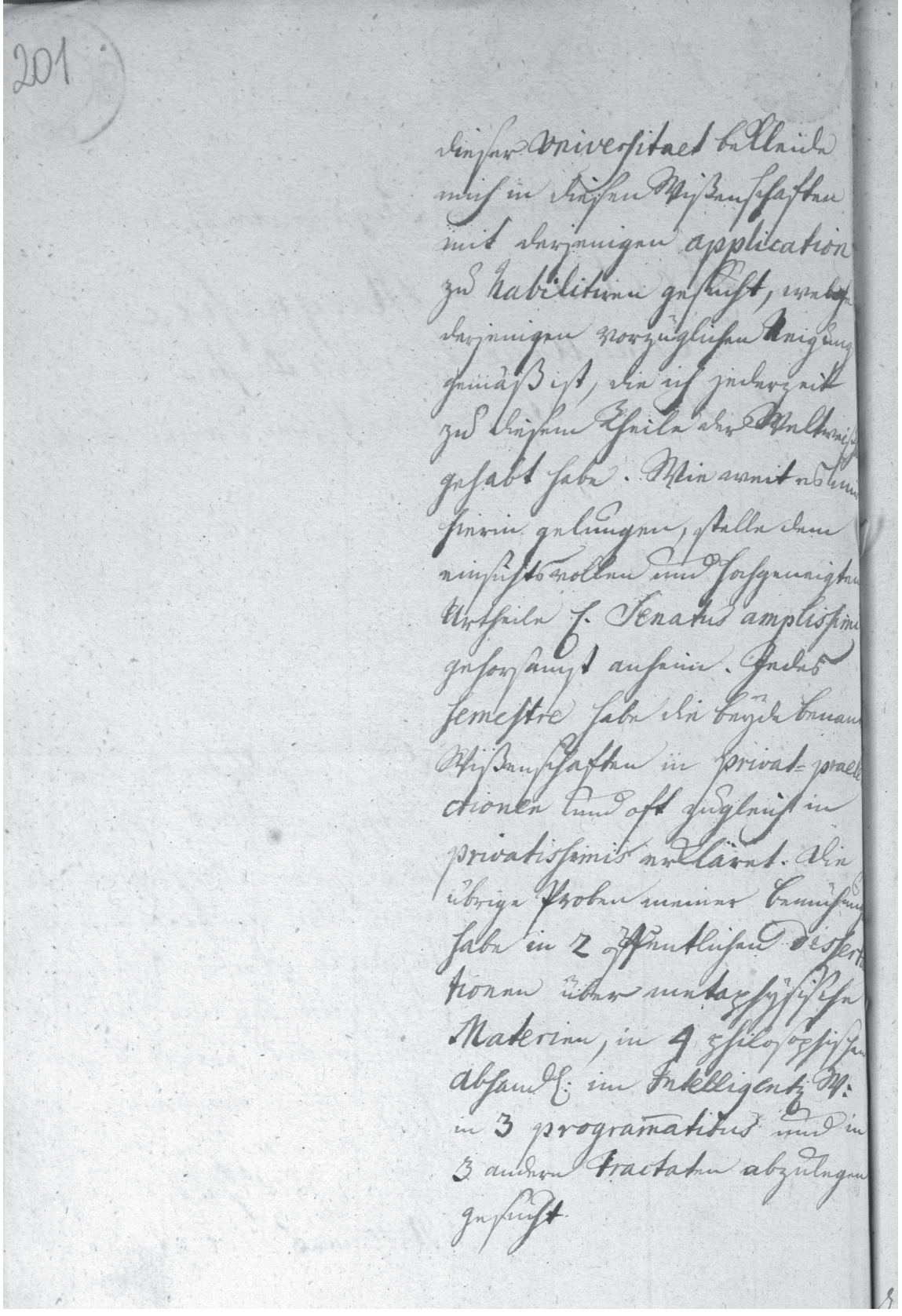




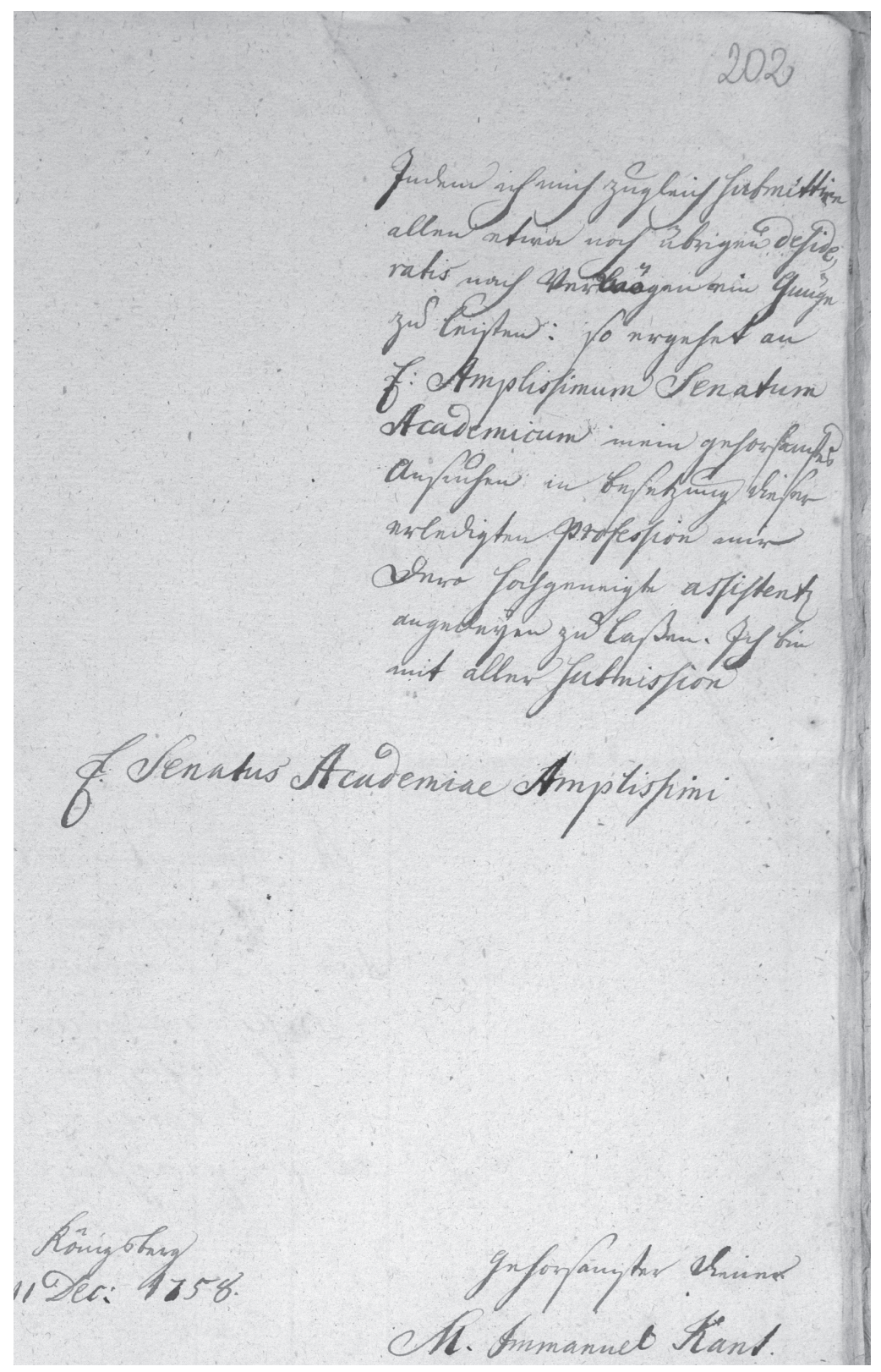

Fot. 1. Podanie Kanta o przyjęcie na etat profesora po śmierci J. Kypkego (APO, sygn. 1646/446, s. 200) 
Academiae Regiomontanae

Rector Magnifice

Cancellarie Director illustris

Amplissimi atque excellentissimi Domini Senatores*

Durch das Absterben des weyl[and] HochEhrw[ürdigen] Doct.[or] u[nd] Prof. [essor] Theol[ogiae] H[err]n Kypke Professoris Ordinarii der Logick und Metaphysic ist die letztere Profession bey der hiesigen Universitaet erledigt worden. Ich habe in meinem vieljährigen academischen curriculo insonderheit seitdem ich die Stelle eines Docenten auf dieser Universitaet bekleide mich in diesen Wißenschaften mit derjenigen Application zu habilitiren gesucht, welche derjenigen vorzüglichen Neigung gemä $\beta$ ist, die ich jederzeit zu diesem Theile der Weltweißheit gehabt habe. Wie weit es mir hierin gelungen, stelle dem einsichtsvollen und hochgeneigten Urteile E.[ures] Senatus amplissimi gehorsamst anheim. Jedes Semestre habe die beyde benante Wißenschaften in privat-praelectionen und oft zugleich in privatissimis erkläret. Die übrige Proben meiner Bemühungen habe in 2 öffentlichen Dissertationen über metaphysische Materien, in 4 philosophischen Abhandl[ungen] im Intelligentz W[erk], in 3 programmatibus und in 3 andere Tractaten abzulegen gesucht. Indem ich mich zugleich submittire allen etwa noch übrigen Desideratis nach Vermögen ein Gänze zu leisten: so ergehet an E.[uren] Amplissimum Senatum Academicum mein gehorsamstes Ansuchen in Besetzung dieser erledigten Profession mir dero hochgeneigte Assistentz angedeyen zu laßen. Ich bin mit aller subnission.

E.[urer] Senatus Academiae Amplissimi

Königsberg d. 11 Dec.[ember] 1758 gehorsamster Diener

M. Immanuel Kant
Magnificencjo Rektorze

Dostojny Dyrektorze Kancelarii

Najczcigodniejsi i najznakomitsi Panowie Senatorowie

Wraz ze śmiercią świętej pamięci Wielmożnego Pana Kypke doktora i profesora teologii, Professoris Ordinarii (profesora zwyczajnego) logiki i metafizyki, wygasła dla tutejszego uniwersytetu ostatnia profesura tej profesji. W czasie mojej wieloletniej pracy akademickiej, w szczególności od kiedy objąłem wakat docenta na tym uniwersytecie, podejmowałem starania habilitacyjne $\mathrm{w}$ owej dziedzinie naukowej, która odpowiada w zupełności skłonnościom (zainteresowaniom), które ja od dawien darzę w stosunku do tego obszaru nauk. Jak dalece to mi się udało, pozostawiam posłusznie sądowi wielce rozumnego i szanownego senatus amplissimi. Każdego semestru, podczas prywatnych prelekcji i często równocześnie $\mathrm{w}$ trakcie privatissimi, prowadziłem wykłady z obszaru tych dwóch dziecin nauki. Moje przemyślenia zawarłem $\mathrm{w}$ dwóch opublikowanych dysertacjach o zagadnieniach metafizycznych, w czterech rozprawach filozoficznych wydanych w błyskotliwym dziele, w trzech programmatibus i trzech pozostałych traktatach. Oddając się całkowicie woli Waszych Ekscelencji Amplissimum Senatum Academicum proszę uniżenie o przydzielenie mi tej wygasłej profesury. W uniżeniu.

Wielce Szanowny Senatus Academiae Amplissimi

Königsberg dnia 11 grudnia 1758

uniżony sługa

M. Immanuel Kant

* Akta fakultetu filozoficznego 1751-1772, APO, sygn. 1646/446 s. 200, a także http://www. korpora.org/kant/aa10/004.html (data dostępu: 28.04.2014). Obie kopie nieznacznie się jednak różnią. 
Swoje starania o etat profesorski Kant motywował dotychczasowymi osiągnięciami naukowymi oraz kilkuletnim doświadczeniem zdobytym jako Privatdozent. Widział siebie w roli wykładowcy metafizyki oraz logiki i był przekonany, że zarówno poziom merytoryczny, popularność wśród słuchaczy głoszonych przez niego wykładów, jak i poziom licznych publikacji naukowych pretendują go do objęcia zaszczytnego stanowiska profesora zwyczajnego. Liczył również na poparcie władców, jak i uniwersyteckich profesorów. Nie ulega wątpliwości, że konsekwencja Kanta w usiłowaniach zdobycia etatu (szczególnie wtedy, gdy tylko w części odpowiadały temu faktyczne kompetencje i osiągnięcia, jak np. przy próbach uzyskania etatu profesora sztuki poetyckiej po zmarłym Bocku) wynikała $\mathrm{z}$ woli zdobycia stałego zatrudnienia, ale przede wszystkim opierała się na przekonaniu o wartości dotychczasowych dokonań oraz o wszechstronnych możliwościach dalszego rozwoju. Starania Kanta o profesurę zakończyły się jednak dopiero w 1770 roku, gdy 16 kwietnia otrzymał etat profesorski w dziedzinie logiki oraz metafizyki na mocy decyzji dziekana Johanna Bernharda Hahna (jun.) ${ }^{27}$. W uzasadnieniu pozytywnej decyzji podkreślano m.in. niebywałą erudycję Kanta w zakresie filozofii.

Profesorski etat Kanta, uzyskany w 1770 roku (formalne objęcie katedry po zmarłym matematyku, Christophie Langhansenie, a następnie zamiana z Buckiem na katedrę logiki i metafizyki) istotnie zdynamizował jego karierę akademicką i umożliwił dalsze awanse. W wymiarze filozoficznym Kant przechodził w tamtym czasie intelektualną metamorfozę. Z jednej strony zyskiwał formalne prawo do wszechstronnej działalności akademickiej, z czym wiązało się zobowiązanie do rozwoju naukowej i badawczej samodzielności ${ }^{28}$, z drugiej zaś rozumiał konieczność zaangażowania się w bieżącą działalność uniwersytetu i wynikające z niej powinności.

\footnotetext{
${ }^{27}$ Akta fakultetu filozoficznego 1751-1772, APO, sygn. 1646/306, fol. 736 i 779.

${ }^{28} \mathrm{O}$. Höffe akcentuje nowatorstwo wykładu inauguracyjnego Kanta, O formie i zasadach świata zmystowego i świata intelligibilnego (De mundi sensibilis atque intelligibilis forma et principiis). Głoszonymi wówczas tezami przynajmniej częściowo antycypował założenia późniejszej filozofii krytycznej. Por. O. Höffe, Immanuel Kant, przeł. A. M. Kaniowski, WN PWN, Warszawa 1995, s. 34-35. Nowatorstwo filozofii krytycznej Kanta wszechstronnie rekonstruuje i komentuje także S. Dietzsch (por. Immanuel Kant..., s. 94-99).
} 
Funkcjonowanie uniwersytetu wymagało od Kanta jako dziekana (po raz pierwszy został nim na początku kwietnia 1776 i sprawował funkcję przez pół roku) równoczesnego angażowania się w sprawy naukowe, a także pozostałe - administracyjne, organizacyjne, dydaktyczne czy nawet finansowe. Kant np. reprezentował fakultet jako strona w nieudanej transakcji kupnasprzedaży domu przy Roßgarten 68 przez ogrodnika Johanna Schütza ${ }^{29}$. Później (1788), jako rektor, Kant pozytywnie opiniował i zatwierdzał decyzję dziekana Reuscha o udzieleniu przez uniwersytet kredytu w wysokości 1400 talarów ${ }^{30}$.

Jednym z zdań, zajmujących Kanta podczas wykonywania obowiązków administracyjnych, było opiniowanie kandydatur do stanowisk uniwersyteckich. Odzwierciedlenie w dokumentach ma m.in. sprawa obsadzenia wakującego stanowiska profesora orientalistyki. Jednym z pism, przygotowanych osobiście przez Kanta, jest opinia o Isaaku Abrahamie Euchelu. Została ona napisana 20 lutego 1786 roku w ślad za listem polecającym profesora Johanna Bernharda Köhlera. W trzydziestoletnim wówczas Euchelu Köhler widział swego następcę. W tej sprawie głos zabrał sam Kant i, mimo różnych wątpliwości oraz formalnych ograniczeń, oczekiwał przychylności ze strony senatu akademickiego. Dietzsch (na podstawie dokumentacji z GStPK w Berlinie Dahlem) przytacza pozytywną opinię Köhlera o Euchelu i jego prośbę o poparcie kandydatury tego żydowskiego publicysty i wydawcy. Dodaje jednak, że istniały obiekcje, wynikające $\mathrm{z}$ wyznania, które ostatecznie uniemożliwiły mianowanie Euchela na stanowisko profesora (dopiero kilka miesięcy później został on zatrudniony jako tłumacz z hebrajskiego i jidysz) ${ }^{31}$.

\footnotetext{
${ }^{29}$ Umowa kupna sprzedaży z 23 V 1776, APO, sygn. 1646/236, fol. 594-595.

${ }^{30}$ Votum Kanta z 18 maja 1788, APO, sygn. 1646/1376, s. 1.

${ }^{31}$ Zob. S. Dietzsch, Fakultet Filozoficzny Uniwersytetu w Królewcu w latach 1744-1844..., s. $48-49$.
} 


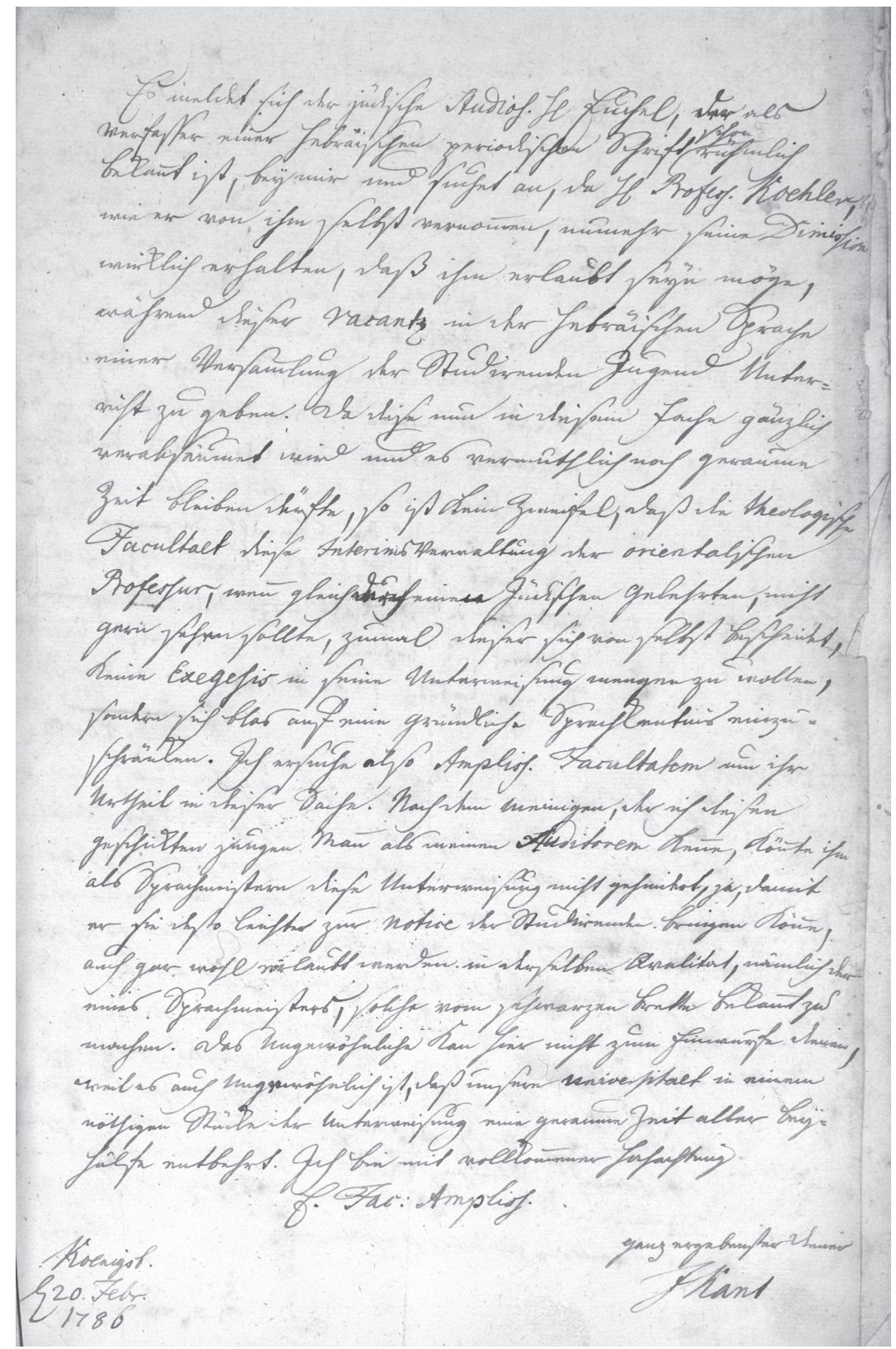

Fot. 2. Opinia Kanta o Euchelu (APO, sygn.1646/150, s. 227) 
Es meldet sich der jüdische Studios.[us] H.[err] Euchel, der als Verfasser einer hebräischen periodischen Schrift schon rühmlich bekannt ist, bey mir und suchet an, da H.[err] Profess.[or] Koehler, wie er von ihm selbst vernommen, nunmehr seine Dimission wirklich erhalten, daß ihm erlaubt seyn möge, während dieser Vacantz in der hebräischen Sprache einer Versammlung der Studirenden Jugend Unterricht zu geben.

Da diese nun in diesem Fache gänzlich verabsäumet wird und es vermuthlich noch geraume Zeit bleiben dürfte, so ist kein Zweifel, daß die theologische Facultaet diese Interimsverwaltung der orientalischen Professur, wenn gleich durch einen Jüdischen Gelehrten, nicht gern sehen sollte, zumal dieser sich von selbst bescheidet, keine Exegesis in seine Unterweisung mengen $\mathrm{zu}$ wollen, sondern sich blos auf eine gründliche Sprachkenntnis einzuschränken. Ich ersuche also Ampliss.[?] Facultatem um ihr Urtheil in dieser Sache. Nach den meinigen, der ich diesen geschickten jungen Mann als meinen Auditorem kenne, könnte ihm als Sprachmeistern diese Unterweisung nicht gehindert, ja, damit er sie desto leichter zur Notice der Studierenden bringen könne, auch gar wohl erlaubt werden in derselben Qvalität, nämlich der eines Sprachmeisters, solche vom Schwarzen Brette bekannt zu machen. Das Ungewöhnliche kann hier nicht zum Einwurfe dienen, weil es auch Ungewöhnlich ist, daß unsere Universitaet in einem nöthigen Stücke der Unterweisung eine geraume Zeit aller Beyhülfe entbehrt. Ich bin mit vollkommener Hochachtung.

E.[?] Fac.[ ?] Ampliss.[?]

Koenigsb.[erg] d.20 Febr. [uar] 1786 ganz ergebenster Diener

IKant
Zgłasza się do mnie żydowski student, pan Euchel, który jest już powszechnie znany jako autor pewnego hebrajskiego periodyku, i stara się, wiedząc od samego profesora Koehlera o właśnie złożonej dymisji, by było mu umożliwione prowadzenie w czasie tego wakatu zajęć $\mathrm{z}$ języka hebrajskiego dla braci studenckiej. Ponieważ język ten zaniedbywany jest na tym kierunku, i pewnie zaniedbywanym będzie jeszcze przez dłuższy czas, to nie podlega żadnej wątpliwości, że fakultet teologiczny nie będzie patrzył łaskawym okiem na to tymczasowe rozwiązanie w kwestii orientalnej profesury, nawet jeśli chodziłoby o żydowskiego naukowca. Tym bardziej, że jak sam oświadczył, nie zamierza do swojej nauki mieszać egzegezy, lecz chce się jedynie ograniczyć do rzetelnej nauki języka. Dlatego zwracam się do Ampliss Facultatem (szanownego fakultetu) z prośbą o wydanie sądu w tej sprawie. Według mego osądu, a znam tego zdolnego młodego człowieka jako mego słuchacza, nie powinno się mu jako znawcy języka robić przeszkód w uczeniu, powiem więcej: by tym łatwiej mógł zwrócić uwagę studentów i zainteresować ich tym językiem, powinien móc jako znawca umieszczać obwieszczenie na tablicy ogłoszeń. Ta wyjątkowa sytuacja nie powinna być traktowana $\mathrm{z}$ wyrzutem, gdyż niecodziennym jest również fakt, że nasz uniwersytet $\mathrm{w}$ niektórych obszarach cierpi od dłuższego czasu na brak koniecznych sił w nauczaniu. Pozostając z najwyższymi wyrazami szacunku.

E.[?] Fac.[ ?] Ampliss.[?]

Koenigsb. 20 lutego 1786 roku

Oddany sługa

IKant 
Warto wspomnieć, że Dietzsch przywołuje tę sprawę dla zilustrowania nieprzychylnego stanowiska senatu przy próbach powierzania ważnych stanowisk uniwersyteckich reprezentantom innych wyznań niż ewangelicko-augsburskie $^{32}$. Nie należy traktować tej praktyki jako formy nietolerancji religijnej, a jako wynik przestrzegania od dawna obowiązujących regulacji prawnych.

Wśród innych dokumentów, których autorem był Kant, warto zwrócić uwagę na prośbę z 26 lutego 1796 roku skierowaną do rektora Albertyny i pochodzącą z okresu, gdy pogarszający się stan zdrowia skutecznie utrudniał lub nawet całkowicie uniemożliwiał wywiązywanie się z powierzonych lub czekających go obowiązków i wymagał znalezienia najkorzystniejszych rozwiązań organizacyjnych. Poniższa prośba Kanta świadczy nie tylko o wynikającej z podeszłego wieku i dolegliwości niezdolności do podjęcia obowiązków administracyjnych, ale także o poczuciu odpowiedzialności i przekonaniu o nieuchronności wycofania się z życia akademickiego.

32 Por. S. Dietzsch, Immanuel Kant..., s. 155. 


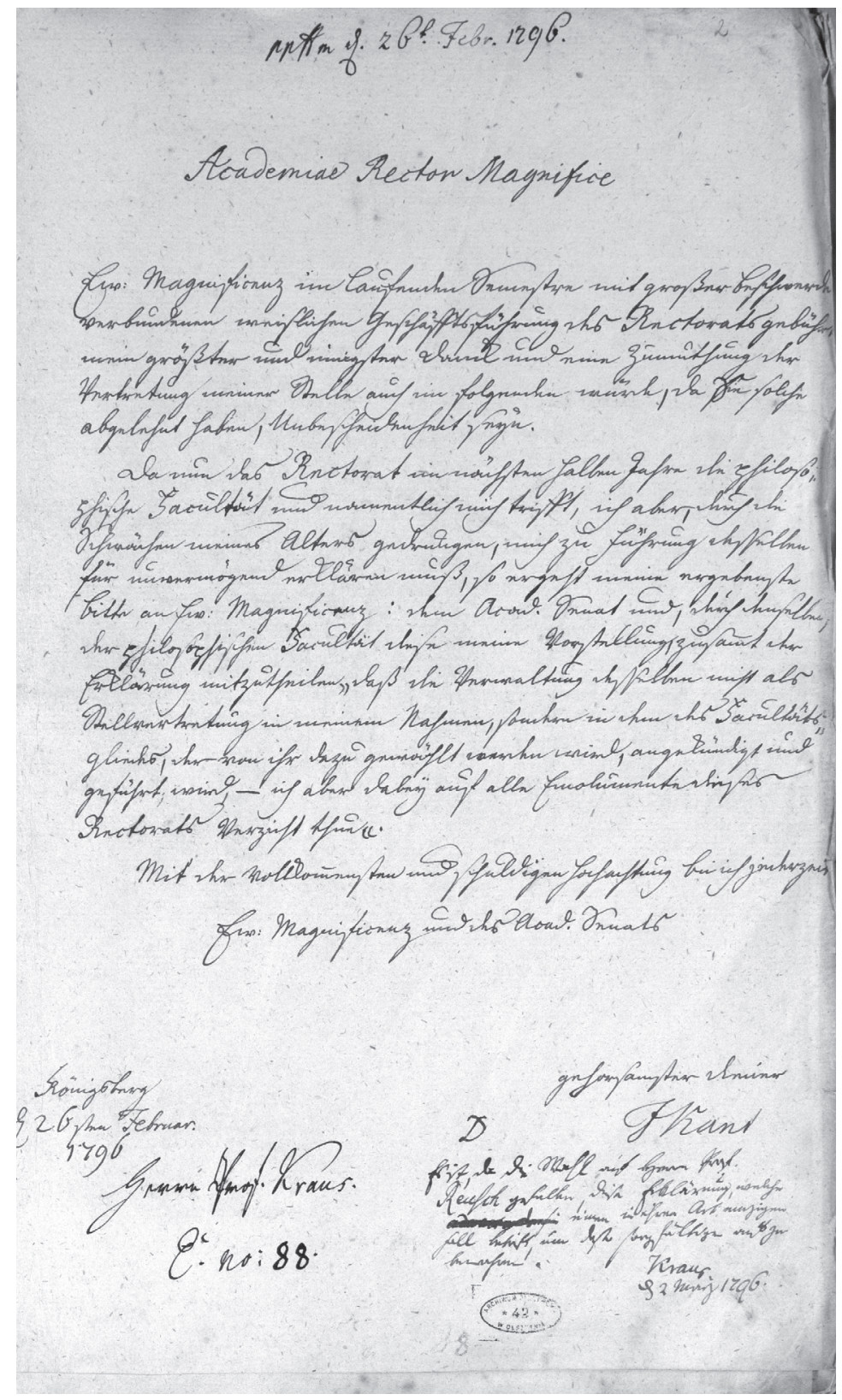

Fot. 3. Prośba Kanta o zwolnienie z czekających go obowiązków służbowych (sygn. 1646/329, s. 2) 
Academiae Rector Magnifice

E. [ure] Magnificenz im laufenden Semester mit großer Beschwerde verbundenen weislichen Geschäftsführung des Rectorats gebührt mein größter und einigster (innigster?) Dank und eine Zumuthung der Vertretung meiner Stelle auch im folgenden würde, da Sie solche abgelehnt haben, Unbescheidenheit seyn.

Da nun das Rectorat im nächsten halben Jahre die philosophische Facultät und namentlich mich trifft, ich aber, durch die Schwächen meines Alters gedrungen, mich zu Führung desselben für unvermögend erklären $m u \beta$, so ergeht meine ergebenste Bitte an E[ure] Magnificenz: dem Acad.[emischen] Senat und, durch denselben, der philosophischen Facultät diese meine Vorstellung, zusammt der Erklärung mitzutheilen „da $\beta$ die Verwaltung desselben nicht als Stellvertretung in meinem Nahmen, sondern in dem des Facultätsgliedes, der von ihr dazu gewählt werden wird, angekündigt und geführt wird, - ich aber dabey (auf?) alle Emolumente dieses Rectorats Verzicht thu(e?)".

Mit der vollkommensten und schuldigen Hochachtung bin (?) ich jederzeit E.[urer] Magnificenz und des Acad. [emischen] Senats

gehorsamster Diener

Königsberg

d.[en] 26sten Februar 1796

IKant
Academiae Rector Magnifice

Waszej Magnificencji należą się wyrazy mojego najgłębszego podziękowania za mądre i związane $\mathrm{z}$ ogromnym trudem kierowanie rektoratem w bieżącym semestrze i przydzielenie zastępstwa na moje miejsce również w semestrze przyszłym, zwłaszcza że Wasza Magnificencja odrzucił tę prośbę, byłoby $\mathrm{z}$ mojej strony nieskromne.

Ponieważ w następnym półroczu sprawowanie władzy rektorskiej przypada wydziałowi filozofii i mnie osobiście, ja jednak, ze względu na ułomności mego późnego wieku, muszę stwierdzić swoją niezdolność do tej funkcji, tym samym pozwalam sobie na skierowanie do Waszej Magnificencji mojej najgłębszej prośby: o przekazanie Senatowi Akademickiemu i poprzez Senat fakultetowi filozoficznemu następującego oświadczenia, „że zarządzanie senatem nie będzie prowadzone w moim imieniu, lecz w imieniu wybranego do tego członka wydziału - ja natomiast rezygnuję przy tym z korzyści wynikających ze sprawowania władzy rektorskiej”.

Przekazując najgłębsze wyrazy szacunku, pozostaję w każdym czasie najuniżeńszym sługą Waszej Magnificencji i Senatu Akademickiego.

Koenigsberg

26 lutego 1796

IKant

Obowiązki dydaktyczne Kanta w tamtym czasie przejmowali jego młodsi koledzy, August W. Wlochatius oraz blisko związany z filozofem profesor poezji, Karl L. Poerschke ${ }^{33}$. Rok po prośbie do rektora i senatu uczelni Kant rezygnuje $\mathrm{z}$ funkcji pełnionych $\mathrm{w}$ fundacji Kypkego. Trzeba dodać, że ostatnim epizodem działalności administracyjnej Kanta był datowany na 15 marca 1803 roku udział w głosowaniu senatu uczelni w sprawie obowiązkowej opłaty za przedwczesne opuszczenie Albertyny przez jej pracowników ${ }^{34}$.

\footnotetext{
33 Tamże, s. 208.

34 Tamże, s. 205.
} 


\section{Podsumowanie}

Zasób oraz nowoczesne środki techniczne olsztyńskiego Archiwum Państwowego pozwalają na przygotowanie oryginalnej i wartościowej publikacji elektronicznej, dającej szersze możliwości pracy ze zdigitalizowanymi dokumentami. Całość zaplanowanych (i częściowo wykonanych już) prac polega $\mathrm{w}$ pierwszej kolejności na tematycznym i chronologicznym wyselekcjonowaniu oraz cyfryzacji dokumentów w formie plików graficznych w wysokiej rozdzielczości, zapisanych w bezstratnym formacie i pozwalających na przeglądanie oraz pracę badawczą jak z oryginalnymi dokumentami. Naukowa część opracowania obejmie odczytanie osiemnastowiecznych rękopisów, ich translację oraz komentarz. Prace są prowadzone przez interdyscyplinarny zespół składający się z archiwisty, filologa germańskiego oraz historyka filozofii, a ich efektem powinna się stać nowoczesna publikacja, której znaczenie wynika nie tylko z wartości zachowanej dokumentacji, ale również z faktu, że stanowi ona część kulturowego i historycznego dziedzictwa dawnych Prus Wschodnich.

\section{Bibliografia}

Bogdan D., Besuch der Vorlesungen durch Studenten der Theologischen Fakultät der Königsberger Universität in den 70er und 80er Jahren des 18. Jahrhunderts, [w:] Studien zur Entwicklung preußischer Universitäten, Hrsg. R. Brandt, W. Euler, Harrassowitz Verlag, Wiesbaden 1999, s. 95-112.

Dietzsch S., Fakultet Filozoficzny Uniwersytetu w Królewcu w latach 1744-1844, „Komunikaty Mazursko-Warmińskie" 1995, nr 1, s. 45-52.

Dietzsch S., Immanuel Kant. Eine Biographie, Leipzig 2003 (polski wyd., przekł. K. Krzemieniowa, Warszawa 2005).

Euler W., Dietzsch S., Der Dekan Immanuel Kant, „Universitas. Zeitschrift für interdisziplinäre Wissenschaft" 1994, Nr. 571, s. 97-98.

Euler W., Dietzsch S., Prüfungspraxis und Universitätsreform in Königsberg. Ein neu aufgefundener Prüfungsbericht Kants aus dem Jahre 1779, [w:] Kant-Forschungen V, Hamburg 1994, s. 91-108.

Euler W., Kant w Senacie akademickim w latach 1780-1801, „Komunikaty MazurskoWarmińskie" 1995, nr 2, s. 131-142;

Euler W., Kantiana in Olsztyn, „Information Philosophie” 1993, H. 4, s. 78.

Euler W., Kants Amtstätigkeit - ein neues Projekt der Kantforschung, „Information Philosophie" 1992, H. 5, s. 76-77. 
Euler W., Kants Beitrag zur Schul- und Univerisitätsreform im ausgehenden 18. Jahrhundert, [w:] Studien zur Entwicklung preußischer Universitäten, hrsg. v. R. Brandt, W. Euler, Harrassowitz Verlag, Wiesbaden 1999, s. 203-272.

Euler W., Kants Beitrag zur Schul- und Universitätsreform im ausgehenden 18. Jahrhundert, [w:], Studien zur Entwicklung preußischer Universitäten, R. Brandt, W. Euler, W. Stark (Hrsg.), Wiesbaden 1999.

Euler W., Stiening Gideon, ... und nie der Pluralität widersprach'? Zur Bedeutung von Immanuel Kants Amtsgeschäften, „Kant-Studien” 1995, Nr 86, s. 54-69.

Höffe O., Immanuel Kant, przeł. A. M. Kaniowski, Warszawa 1995.

Judziński J., Archiwum Państwowe w Olsztynie 1945-1995, [w:] Pół wieku polskiej państwowej służby archiwalnej na ziemiach zachodnich i pótnocnych, red. Kazimierz Kozłowski, Warszawa-Szczecin 1997, s. 119-140.

Kant Forschungsstelle der Johannes Guttenberg-Universität Mainz, http://www.kant. uni-mainz.de/ (data dostępu: 7.04.2014).

Kant I., Spór fakultetów, [w:] tenże, Dzieła zebrane, t. 5, red. W. Włoch, przeł. M. Żelazny, Torun 2011, s. 194-285.

Marburger Archiv - Kant und die Aufklärung, http://www.uni-marburg.de/fb03/philosophie/mr_archiv (data dostępu: 7.04.2014).

Marti H., Die Quellenbestände zur frühneuzeitlichen Königsberger Universitätsgeschichte im polnischen Olsztyn (Allenstein) - Ein erster fragmentarischer Überblick, [w:] Königsberger Buch- und Bibliotheksgeschichte, Hrsg. A. E. Walter, Böhlau Verlag, Köln-Weimar-Wien 2004, s. 571-582.

Stark W., Kant als akademischer Lehrer, [w]: Wolfenbütteler Studien zur Aufklärung, Bd. 16, Hrsg. H. Ischreyt., Max Niemeyer Verlag, Tübingen 1995, s. 51-68.

Stark W., Kants Amtstätigkeit. Ein Kurzbericht zu einem Vorhaben der Deutschen Forschungsgemeinschaft, „Kant-Studien” 1994, Nr 85, s. 470-472.

Stiening G., Der t 'Strich des Zensors' und die 'Freiheit der gelehrten Feder'. Immanuel Kant und die Universitätszensur, [w:] Studien zur Entwicklung preußischer Universitäten..., s. 163-201.

Stiening G., Immanuel Kant i historia Fakultetu Medycyny w Królewcu, „Komunikaty Mazursko-Warmińskie" 1995, nr 1, s. 53-64.

The Dictionary of Eighteenth Century German Philosophers, 3 vols., Manfred Kühn and Heiner Klemme (ed.), Continuum, London-New York 2010; http://www. manchester.edu/kant/bio/FullBio/KypkeJD.html (data dostępu: 24.04.2014); http://www.manchester.edu/kant/bio/biokon.htm\#KypkeJD (data dostępu: 24.04.2014)

Wacławik B., Akta Wydziału Filozoficznego Uniwersytetu w Królewcu przechowywane w Archiwum Państwowym w Olsztynie, [w:] Historia. Archiwistyka. Informacja Naukowa, red. Marzena Świgoń, Wyd. UWM w Olsztynie, Olsztyn 2009, s. 229-231. 
Wacławik B., Archiwalia do dziejów Uniwersytetu Królewieckiego przechowywane w Archiwum Państwowym w Olsztynie, „Archeion” 1995, t. XCV, s. 58-65.

Wacławik B., Die Tätigkeit des Senats der Königsberger Universität im Spiegel von Protokolen der Jahre 1725-1795, [w:] Studien zur Entwicklung preußischer Universitäten, Hrsg. R. Brandt, W. Euler, Harrassowitz Verlag, Wiesbaden 1999, s. 81-94.

Materiały archiwalne:

Rejestr finansowy. APO, sygn. 1646/301 s. 228/229.

Akta fakultetu filozoficznego 1751-1772, APO, sygn. 1646/306, fol. 736 i 779.

Umowa kupna sprzedaży z 23 V 1776, APO, sygn. 1646/236, fol. 594-595.

Votum Kanta z 18 maja 1788, APO, sygn. 1646/1376, s. 1.

Podanie Kanta o przyjęcie na etat profesora po śmierci J. Kypkego, APO, sygn. 1646/446, s. 200.

Opinia Kanta o Euchelu, APO, sygn. 1646/150, s. 227.

Prośba Kanta o zwolnienie z obowiązków służbowych, APO, sygn. 1646/329, s. 2.

\begin{abstract}
Kant's Archive Material in the State Archives in Olsztyn - Research Report

The authors of the article present the basic assumptions of the project designed to prepare and publish the documents preserved in the collection of the State Archive in Olsztyn (APO) and related to Immanuel Kant's academic activity. The article contains a characteristic of the archive material coming from the University of Albrecht in Königsberg, the results of early German research on Kant's academic activity (Kants Amtstätigkeit project) and a presentation of selected documents connected with his work at university as an ordinary professor, as a dean of the faculty of philosophy, and as a rector.
\end{abstract}

Key words: Kant, University of Albrecht in Königsberg, State Archive in Olsztyn, archive material 